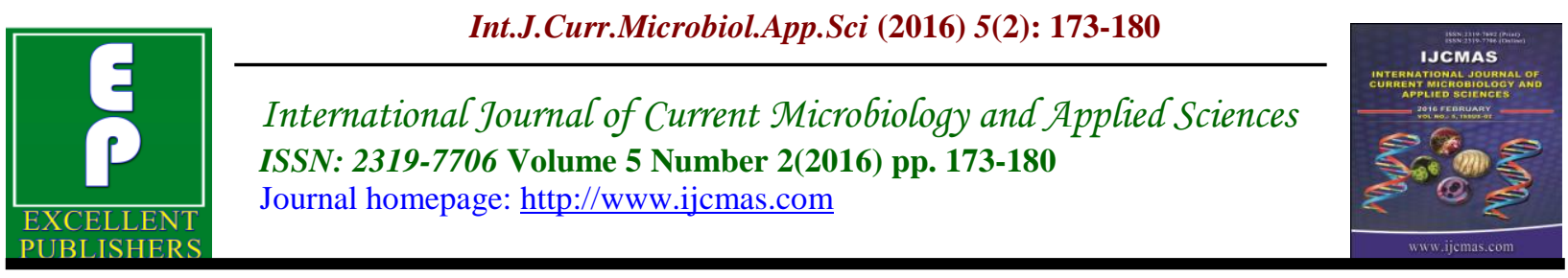

Original Research Article doi: http://dx.doi.org/10.20546/ijcmas.2016.502.020

\title{
Physical and chemical analysis of mullaiperiyar river water in Theni district, Tamilnadu, India
}

\author{
P.Sivamanikandan ${ }^{1} *$ and S.Ahmed john ${ }^{2}$ \\ ${ }^{1}$ Research Scholar, Research and Development Center, Bharathiar University, \\ Coimbatore 641046, Tamilnadu, India \\ ${ }^{2}$ Department of Botany, Jamal Mohamed College (Autonomous), Tiruchirappalli-620020, \\ Tamilnadu, India \\ *Corresponding author
}

\begin{abstract}
A B S T R A C T
Keywords

Mullaiperiyar

River, Theni

district, Total

hardness, BOD,

Dissolved

oxygen, APHA, sanitation

\section{Article Info}

Accepted:

13 January 2016

Available Online:

10, February 2016

Water is a natural resource for the survival of all existing organisms. The Mullaiperiyar River is one of the exceptional rivers of South India. The present study was mainly focused to investigate the physical and chemical analysis of Mullaiperiyar river water in Theni district, Tamilnadu, India. Water samples were collected from the upstream area (Near the Dam-Lower camp, Kullapagoundanpatty, Karunakkamuthan Patty), urban stretch area (Surlipatti, Uthamapalayam, Chinnamanur and Veerapandi) and downstream area (TheniAranmanaipudur, Vaigai Dam) during the period of during the period of six months from January to June 2015 for the analysis. The Physico-chemical parameters were analyzed by using APHA and WHO standard procedure. The observed values of different physical and chemical parameters like Temperature, $\mathrm{pH}$, Total dissolved solids (TDS), Total hardness (TH), Total Alkalinity (TA), Calcium Hardness, Magnesium Hardness, Chloride, Nitrate, Nitrites, Dissolved oxygen (DO), Biochemical Oxygen Demand (BOD), Chemical oxygen demand (COD) was also performed. The present study alerts the inhabitant's sanitation, health activities and environmental hygiene. A regularly observed and ensured the river water quality from additional unhygienic.
\end{abstract}

\section{Introduction}

River is one of the most important development resources for purpose in both rural and urban areas. Rivers are essential and susceptible freshwater environment that are critical for the nourishment of all existence. Water constitutes about 85 to $90 \%$ in manipulate of the human body
(Bello Temitope et al., 2013). Approximately half of the humankind is without access to improved hygiene facilities and almost huge of public still lack to enhanced drinking-water supplies (Oladipo et al., 2009). The large quantity of the world's inhabitant's uses potable water 
for home sanitation, drinking, and cooking purposes (WHO, 2004). During the recent several decades, the Indian rivers water quality has been deteriorating due to incessant discharge of domestic sewage, agricultural and industrial wastes. (Kadarshahib Roshine begam and Sundaraj Selvakumar, 2014). The present study focuses on the effect of physical and chemical factor of Mullaiperiyar river water and an attempt has been made to determine the quality of Mullaiperiyar river water in Theni district.

The Mullaiperiyar river is situated within Latitudes 9'31'43 North and Longitudes $77^{\circ} 8^{\prime} 39^{\prime}$ East beside with the rivers flowing west throughout Kerala State and accordingly the name is Mullaiperiyar river. The Mullaiperiyar River was mostly useful to Theni district people. Theni town is located in the southwestern central part of Tamilnadu $\left(9^{\circ} .39^{\prime} \mathrm{N}\right.$ and $10^{\prime} 30$ north latitude and $77^{\circ} .00$ 'and $78^{\prime} 30$ of east longitude). The Theni district had a population of 1,246 million as per 2011 censes of India Figure 1. Generally, the Mullaiperiyar river water is the major source for drinking, agriculture, washing, bathing and religious purposes in both urban and rural areas. The Mullaiperiyar River receives large amount of wastes such as domestic, industrial and agricultural effluents is directly receiving from townships like Guddalur, Surlipatti, Cumbum, Uthamapalayam, Veerapandi, Theni, Kunnur and Vaigai dam (Sivamanikandan and Ahmed john, 2015). The deterioration of river water quality is mainly exaggerated by human being behaviors such as discharge of sewage, industrial wastes and agricultural runoff which causes systematic ecological damage and health hazards (Meitei et al., 2004; Shrivastav et al., 2013). The major problems are related with river water are solid suspensions, turbidity and lack of oxygen, excess of carbon dioxides and organic biomass. The Physico-chemical factors were indicated that the river water and significantly the beneficial microflora has been reduced by xenobiotic compounds may direct to the existence of these complex by anthropogenic activities (Venkateshraju et al, 2010). The unreliable physicochemical assets of the river water leads to the accumulation of microbial load. Randomly the dumping of sewage and effluent wastes into river changes the physicochemical properties of water production is not fitting for human utilization (Islam et al., 2012). The good quality of river water is an assurance in human health and the protection of the ecosystems and sustainable improvement (Rajini et al., 2010). At present, Siva and Ramakrishnan et al researcher have carried out studies on the Mullaiperiyar Periyar River is greatly polluted with industrial and agricultural wastes. These findings demonstrated the non potability of Mullaiperiyar river water and in the direction of augment alertness to the people and maintain the Mullaiperiyar river water in hygiene stage. Hence, the present study is examined about the physical and chemical analysis in Mullaiperiyar river water in various areas from the month of January 2015 to June 2015.

\section{Materials and Methods}

\section{Study Area}

The study area was divided into nine sampling stations Figure 2. River water samples were collected from nine sampling stations from upstream area as Lower camp (S1), KullapaGoundanpatty (S2), KarunakkaMuthan Patti (S3); middle of urban stretch area as Surlipatti (S4), Uthamapalayam (S5), Chinnamanur (S6) Veerapandi (S7) and downstream area as 
Theni Aranmanaipudur (S8) and Vaigai dam (S9).(Sivamanikandan and Ahmed john, 2015).

\section{Collection of Water Sample}

The Mullaiperiyar river water samples were collected during January to June 2015 from the lower camp to Vaigai dam for the assessment of physico-chemical factors. River water Samples were collected during the first and third week of every month in sterile one liter polythenes bottles. The closed bottles were immersed in the river at the depth of 0.5 to $0.7 \mathrm{~m}$ and the stopper was opened in bottom of river and was closed again to the river water. After sample collection, the bottles were kept in ice box and transferred immediately to the laboratory for further analyses. (Sivamanikandan and Ahmed john, 2015)

\section{Analysis of Water}

The laboratory analysis of Mullaiperiyar river water samples were prepared by the standard procedures of the American Public Health Association (APHA, 2005) and World Health Organization (WHO, 2004). Totally fifteen types of physico-chemical parameters such as Temperature, $\mathrm{pH}$, Electrical conductivity (EC), Total Suspended Solids (TSS), Total alkalinity, Total Hardness, Dissolved Oxygen, Biochemical Oxygen Demand (BOD), Chemical Oxygen Demand (COD); Quantification of Calcium, Magnesium, Nitrate, Nitrite, Chloride, Iron, were performed. The $\mathrm{pH}$ and Temperature of the river water samples were measured at the site using digital $\mathrm{pH}$ meter and digital thermometer respectively. The results were expressed in $\mathrm{mgl}^{-1}$

\section{Results and Discussion}

The physico and chemical assessment of
Mullaiperiyar river water samples were analysed in the nine areas during the period of January 2015 to June 2015. The physical and chemical parameters were higher than their acceptable limits like WHO (2004) and APHA (2005). The mean value of physicochemical parameters of Mullaiperiyar River was presented in the Table 1 .

pH: pH are most significant physical parts that change the chemical and biological effect in the river water. The value of $\mathrm{pH}$ was determined by digital $\mathrm{pH}$ meter. The $\mathrm{pH}$ ranged from 6.8 to 7.4 among in nine stations of river water was analysed. The variation of $\mathrm{pH}$ value to changes in the photosynthetic activities of river plants and increases the utilization of carbonates/carbon dioxide during the process (Gray, 2006). The difference of $\mathrm{pH}$ is appropriate to the variation of discharges from the domestic sewage waste (Raja et al., 2008).

Temperature: River water temperatures are fluctuating with changing climatic situation. The measurement of temperature was determined by using thermometer. The value of temperature ranged from $26^{\circ} \mathrm{C}$ to $27.50^{\circ} \mathrm{C}$ in all water sources respectively. The variation of temperature in river water is generally depends on the season and geographic position, (Ahipathi and Puttaiah, 2006).

EC: The electrical conductivity (EC) was recorded with a minimum value of $930 \mu \mathrm{S} / \mathrm{cmat}$ station 1 and maximum of 1550 $\mu \mathrm{S} / \mathrm{cm}$ at station 9. The high EC specified larger quantities of dissolved minerals like phosphates, carbonates, ammonia and nitrate, etc. due to microbial degradation of the natural wastes (Abida and Harikrishna, 2008; Gray, 2006).

TDS: Total dissolved solids are mainly 
composed of carbonates, bicarbonates, phosphates, chlorides, and nitrates of calcium, magnesium, potassium, sodium, and organic matter and other particles (Mahananda et al., 2010). The amount of total dissolved solids was measured in all nine station ranged from 1320 to $1575 \mathrm{mg} / \mathrm{l}$ was recorded. The high value of TDS present in the river due to the contamination of domestic sewage water, agriculture waste and other garbage. The high concentrations of TDS of the river water were effect into eutrophication of river water sources (Verma Pradeep et al., 2012).

Dissolved Oxygen: The dissolved oxygen of Mullaiperiyar river sample was measured by Winkler's method. The values of DO in nine stations fluctuate from 230 to $275 \mathrm{mg} / \mathrm{l}$. The high level of DO content was due to large decomposition of organic matter with indicates the large amount of pollution in the river water (Radha Krishnan et al., 2007).

BOD: Biochemical oxygen demand (BOD) of the river water test was enumerated by Winkler methods respectively. The value of BOD in nine stations ranged from 7.5 to $50.5 \mathrm{mg} / \mathrm{l}$ in the same way. The BOD is increased due to the sewage discharge, open defecation and urban runoff. (Ahiarakwem and Onyekuru, 2011)

COD: The measure of COD determines the amount of organic matter found in river water (Faith, 2006). Chemical oxygen demand (COD) of the Mullaiperiyar river water sample was measured by Reflux method respectively. The value of COD in nine stations of Mullaiperiyar river water ranged from 11 to $110 \mathrm{mg} / \mathrm{l}$. COD is one of the useful indicators of organic and inorganic substance of river water by sewage discharge and anthropogenic activities (Sivamanikandan and Ahmed john, 2015).
Total Alkalinity: Alkalinity is the defense capacity of a water body (Borlongan et al., 2010). Total alkalinity in river water samples were measured by Acid titration method. The amount of total alkalinity recorded in Mullaiperiyar river ranges between 280 to $920 \mathrm{mg} / \mathrm{l}$.In this study, total alkalinity in all areas was above the standard level. The dumping of domestic, agricultural and industrial wastes is increased alkalinity assortment (Osibanjo et al., 2011).

Total Hardness: Total hardness is dependent upon the quantity of calcium or magnesium salts (APHA 1998; Adejuwon and Adelakun, 2012). Total hardness of river water samples was measured by Ethylene diamine tetra acidic acid (EDTA) titration method. The value of hardness ranged from 240 to $1100 \mathrm{mg} / \mathrm{l}$ in the nine stations of Mullaiperiyar River. The huge amount of total hardness is due to assimilation of sewage effluents into the river (Roy and Kumar, 2002).

Calcium and Magnesium: The calcium and magnesium in the river samples were measured by EDTA titration. The value of calcium and magnesium ranged from 150 to $180 \mathrm{mg} / \mathrm{l}$ and 130 to $160 \mathrm{mg} / \mathrm{l}$ respectively. Calcium is generally present in river water as the carbonate, bicarbonate, sulphate, chloride and nitrate forming permanent hardness (Adejuwon and Adelakun, 2012). The large amount of calcium may be access by discharge of the rocks into the river water organization (Sivakumar et al., 2011). Magnesium is one of the important sources for chlorophyll development and it acts as a restrictive factor for the growth of phytoplankton (Dagaonkar and Saksena, D.N, 1992).

Chloride: Chloride was measured by Argentometric Method and the value was observed within the range from 265 to 320 
$\mathrm{mg} / \mathrm{l}$. In the present study, large quantity of chloride presence in the Mullaiperiyar River is mostly used of high potash fertilizer by the cultivator, washing-cloths, humananimal waste discharge and additionally the septic tank discharge throughout the river flow. The previous work by Sivamanikandan and Ahmed john reports the chloride content of Mullaiperiyar river water to be 285 to $355 \mathrm{mg} / \mathrm{l}$.

Table.1 Physical and Chemical Analysis of Mullaiperiyar River Water in Theni District

\begin{tabular}{|l|c|c|c|c|c|c|c|c|c|}
\hline Parameters & S1 & S2 & S3 & S4 & S5 & S6 & S7 & S8 & S9 \\
\hline pH & 6.8 & 7.0 & 7.0 & 7.2 & 7.4 & 7.5 & 7.5 & 7.2 & 7.4 \\
\hline Temperature & 26 & 26.50 & 27.10 & 27.75 & 28.50 & 27.50 & 27.10 & 28.50 & 27.50 \\
\hline Electrical Conductivity $(\mu \mathrm{S} / \mathrm{cm})$ & 930 & 950 & 975 & 1100 & 1150 & 1190 & 1125 & 1350 & 1550 \\
\hline TDS mg/L & 1320 & 1200 & 1075 & 985 & 950 & 975 & 1100 & 1350 & 1575 \\
\hline Dissolved Oxygen & 230 & 225 & 210 & 180 & 165 & 140 & 125 & 220 & 275 \\
\hline $\begin{array}{l}\text { Biochemical Oxygen Demand } \\
(\mathrm{mg} / \mathrm{L})\end{array}$ & 7.5 & 8.0 & 10.5 & 13.5 & 16.0 & 18.5 & 22.0 & 32.5 & 50.5 \\
\hline $\begin{array}{l}\text { Chemical Oxygen Demand } \\
\text { (mg/L) }\end{array}$ & 11.0 & 11.5 & 14.0 & 16.5 & 18.5 & 23.0 & 28.5 & 62.5 & 110 \\
\hline Total Alkalinity $(\mathrm{mg} / \mathrm{L})$ & 280 & 285 & 290 & 300 & 325 & 345 & 420 & 675 & 920 \\
\hline Total Hardness $(\mathrm{mg} / \mathrm{L})$ & 240 & 255 & 270 & 295 & 340 & 365 & 425 & 785 & 1100 \\
\hline Calcium Hardness $(\mathrm{mg} / \mathrm{L})$ & 150 & 145 & 135 & 120 & 110 & 95.0 & 100.5 & 125 & 180 \\
\hline Magnesium Hardness $(\mathrm{mg} / \mathrm{L})$ & 130 & 120 & 115 & 90 & 85 & 85 & 90 & 115 & 160 \\
\hline Chloride $(\mathrm{mg} / \mathrm{L})$ & 265 & 250 & 225 & 180 & 165 & 150 & 170 & 255 & 320 \\
\hline Nitrate $(\mathrm{mg} / \mathrm{L})$ & 4.50 & 4.65 & 4.85 & 5.20 & 5.55 & 5.75 & 6.20 & 7.25 & 7.65 \\
\hline Nitrite $(\mathrm{mg} / \mathrm{L})$ & 0.50 & 0.50 & 0.50 & 0.52 & 0.45 & 0.42 & 0.45 & 0.52 & 0.55 \\
\hline Iron $(\mathrm{mg} / \mathrm{L})$ & 6.25 & 6.20 & 5.50 & 4.50 & 3.25 & 3.15 & 2.45 & 4.55 & 5.30 \\
\hline
\end{tabular}

Mean values of physical and chemical parameters of Mullaiperiyar river water in Lower camp to Vaigai dam (values are in mg/L, except pH, Temperature and EC). Here,S1- Lower camp, S2- Kullapagoundan patty, S3- Karunakkamuthan Patti, S4Surlipatti, S5- Uthamapalayam, S6- Chinnamanur, S7- Veerapandi, S8- Theni Aranmanaipudur, S9- Vaigai dam

Figure.1 Outline Map of Tamilnadu

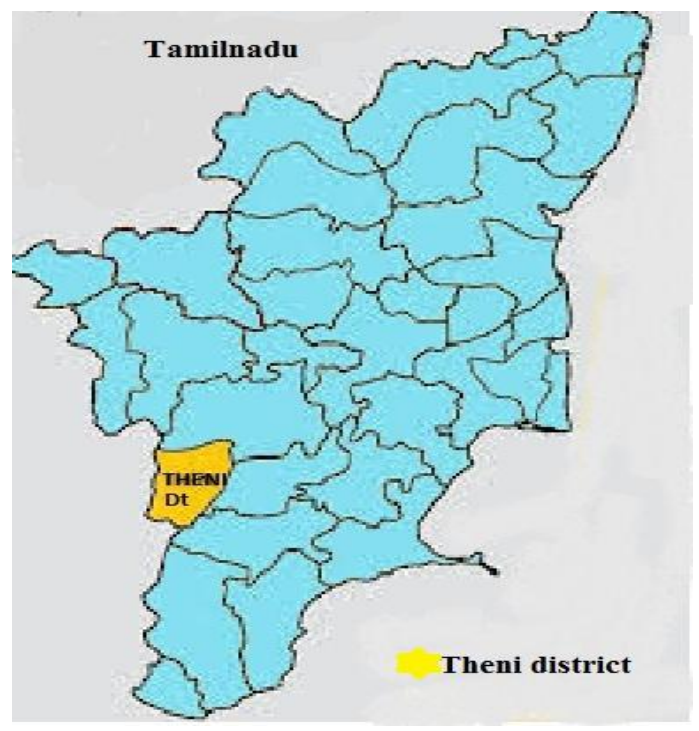


Figure.2 Map of Mullaiperiyar River in Nine Sampling Stations- Theni District

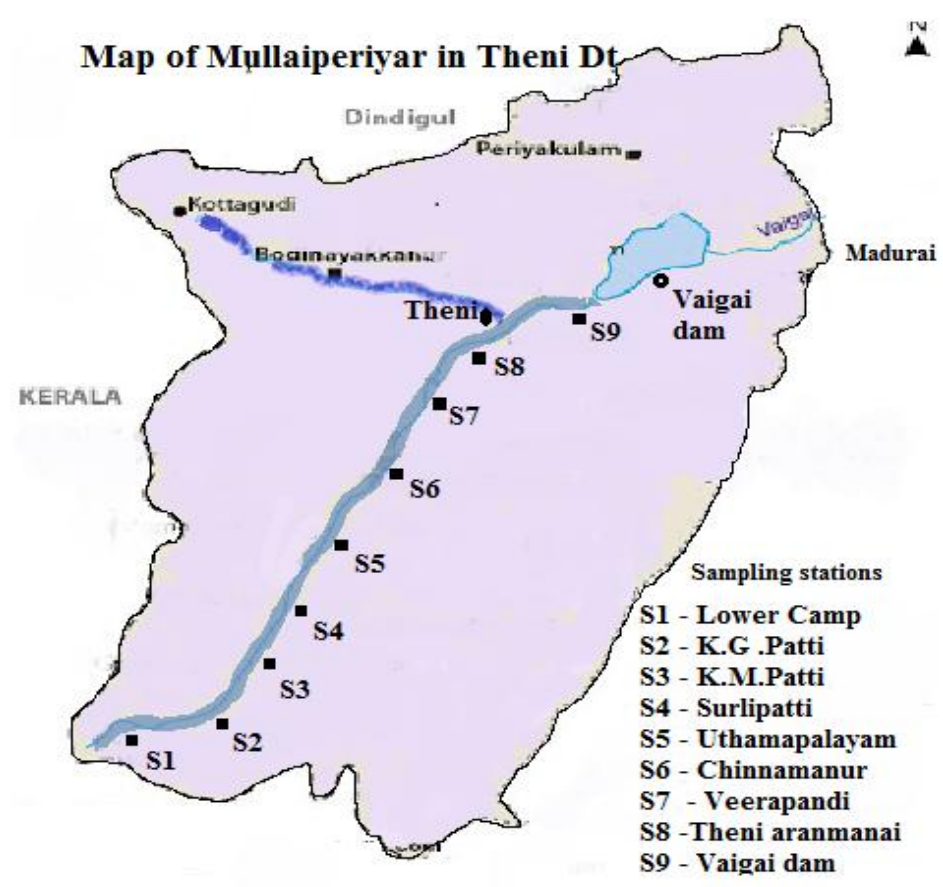

Nitrate and Nitrite: Nitrate and Nitrite is the most importance source of biological oxidation of organic nitrogenous materials. The mean values of nitrate and nitrite in all nine stations were observed at a range from 4.50 to $7.65 \mathrm{mg} / \mathrm{l}$ and 0.50 to $5.55 \mathrm{mg} / \mathrm{l}$.The increases of nitrate in river water can also be recognized to agricultural waste and human and animal wastes. Artificial manure waste, human and animal feces can be the most important source of river water. These augmented amounts of nitrate were originated to stimulate the aquatic plants and thereby added to the BOD level in the river (Peavey et al., 1985; Lalitha et al., 2003).

Iron: In Mullaiperiyar River Iron was detected by Phenanthroline spectrophotometric method. Iron ranged from 6.25 to $5.30 \mathrm{mg} / \mathrm{l}$ in all nine stations. The high concentrations of iron are produced direct and indirect toxic effects on the river biota (Peuranen et al., 1994).

In conclusion, the present study was concluded that Mullaiperiyar river water was highly polluted due to the discharging of solid waste such as domestic and municipal waste, mixing human and animal feces, industrial and agricultural waste like pesticides, and fertilizers released into river water. The physico chemical analysis reveals the current status of river quality is most probably not fit for drinking purpose. The quality of physico-chemical increase within the standard limits of $\mathrm{WHO}$ and APHA standards. This indicates that the water of Theni city and its surrounding area is not suitable for drinking purposes directly if development river water resources are protected hygienically.

\section{References}

Abida, B., and Harikrishna. 2008. Study on the Quality of Water in Some Streams 
of Cauvery River. E- Journal of Chemistry., 5(2): 377-384.

Adejuwon, J. O., and Adelakun, M. A. 2012. Physiochemical and bacteriological analysis of surface water in Ewekoro Local Government Area of Ogun State, Nigeria. Int.J.Water.Res.Environ.Eng., 4(3): 66-72.

Ahiarakwem, C. A., Onyekuru, S. O. 2011. A Comparative Assessment of the Physico-Chemical and Microbial Trends in Njaba River, Niger Delta Basin, Southeastern Nigeria. JWARP., 3: $686-693$.

Ahipathi, M.V., and Puttaiah, E.T. 2006. "Ecological Characteristics of Vrishabhavathi River in Bangalore, India. Environmental Geology., 49: 1217- 1222.

APHA. 2005. Standard Methods for Examination of Water and Wastewater, 21st edn, American Public Health Association, Washington DC,USA.

APHA. 1998. Standard methods for the examination of water and wastewater. $20^{\text {th }}$ Edn, American Public Health Association, Washington DC,USA.

Bello Temitope, K., Bello Olorunjuwon, O., Egberongbe, H.O., AzeezIkimot, A., and OluwadunAfolabi. 2013. Antibiotics resistance profile of Escherichia coli and enterobacteraerogenes isolated from well waters in ago-iwoye, southwestern Nigeria. J. Adv.Bio.,2(2):135-144.

Borlongan, I.G., Golez, N.V., and Lorque, F. 2010. Physicochemical assessment of the Jalaur river system, Iloilo, Philippines. Siliman Journal., 51(1):224-246.

Dagaonkar, A., and Saksena, D.N. 1992. Physicochemical and biological characterization of a temple tank, Kaila Sagar, Gwalior, Madhya Pradesh. J. Hydrobiol., 8 (1): 11-19,
Faith Ngwenya. 2006. Water Quality Trends in the Eerste River, Western Cape, 1990- 2005. A mini thesis submitted in partial fulfillment of the requirements for the degree of Magister Scientiae, Integrated Water Resources Management in the Faculty of Natural Science, University of the Western Cape. pp. 41.

Gray, N.F. 2006.Water Technology. An Introduction for Environmental Scientists and Engineers. 2nd Edn. Elsevier India Pvt. Ltd. New Delhi,.)

Islam, M. S., Tusher, T. R., Mustafa, M., and Mahmud, S. (2012). Effects of solid waste and industry al effluents on water quality of Turag River at Konabari industrial area, Gazipur, Bangladesh. $J$. Environ. Sci.\& and Natural Resources., 5(2): 213-218.

Kadarshahib Roshinebegam and Sundaraj Selvakumar. 2014. Seasonal Changes in Physico-Chemical Parameters of MullaiPeriyar River, Tamil Nadu, India. Chem. Sci. Rev. Lett., 3(9): 66-73.

Lalitha, S., Kasthuri, R., Kalaivani, D., Banumathi, K., and Akilandeshwari, L. 2003. Impact of Sewage Disposal on Quality of Water near Chinthamani, Tiruchirappalli. IJEP., 23: 1268-1271.

Mahananda, M.R. Mohanty,B.P., and Behera,N.R. 2010. "Physico-Chemical analysis of surface water and ground water of Bargarh District, Orissa, India. IJRRAS, 2 (3): 284-295.

Meitei, N.S., Bhargava, and V., Patil, P.M. 2004.Water quality of Purna river in Purna Town, Maharashtra state. J. Aqua. Biol, 19: 77-78.

Oladipo, I.C., Onyenike. I.C., and Adebiyi, A.O.2009. Microbiological analysis of some vended sachet water in Ogbomoso, Nigeria. Afr. J.Food Sci., 3(12):406-412.

Osibanjo, O., Daso, A. P., and Gbadebo, A.M. 2011. The impact of industries on 
surface water quality of River Ona and River Alaro in Oluyole Industrial Estate, Ibadan, Nigeria. Afr.J. Biotechnol., 10 (4): 696-702.

Peavey, H.S., Rowe, D.R., and Tchobanoglous, G. 1985. Environmental Engineering, McGrawHill Book Company, Singapore.

Peuranen, S., Vuorinen, P.J., Vuorinen, M., and Hollender, A. 1994. The effects of iron, humic acids and low $\mathrm{pH}$ on the gills and physiology of brown trout (salmotrutta). Ann. Zool. Fenn. 31: 389396.

Rajini, K., Roland, P., John, C., and Vincent, R. 2010. Microbiological and physicochemical analysis of drinking water in George Town. Nature and Science.,8(8): 261-265.

Raja., P., MuhindharAmarnath, A., Elangovan, R., and Palanivel, M. 2008. Evaluation of physical and chemical parameters of river Kaveri, Tiruchirappalli, Tamil Nadu. Ind. J. Environ. Biol. 29(5): 765-768.

Radha Krishnan, R., Dharmaraj, K., and RanjithaKumari, B.D. 2007. A comparative study on the physicochemical and bacterial analysis of drinking, borewell and sewage water in the three different places of Sivakasi. J. Environ. Biol., 28(1):105-108.

Roy, Y., and Kumar, R. A. 2002. A study of water quality of the rivers of Ranchi district. Ind. J. Environ. Protec., 21(5): 398-402.
Sivakumar, K.K., Balamurugan, C., Ramakrishnan, D.,and LeenaHebsibai, L. 2011. Studies on physico chemical analysis of ground water in Amaravathi river basin at Karur (Tamil Nadu), India. Water $R$ and D., 1(1): 36-39.

Sivamanikandan, P., and Ahmed john, S. 2015, Impact of physico-chemical parameters on bacterial population in Mullaiperiyar River water-Theni district, Tamilnadu, India. Afr.J.Microbiol.Res, 9(1): 26-32.

Shrivastava, N., Mishra,D.D., Mishra,P.K., and Bajpai,A. 2013. Water quality deterioration machna River due to Sewage Disposal, Betul, Madhya Pradesh, India. J. Env. Earth. Sci., 3: 15.

Venkateshraju, K., Ravikuamr, P., Soma Shankar, R. K., and Prakash, K. L. 2010, Physicochemical and bacteriological investigations of the river Cauvery of Kollegal stretch in Karnataka, Kathamandu university. $J$. sci. and engineering and technol., 6 (1):50-59.

VermaPradeep., Chandawat Deepika., Gupta Urvi., and Solanki Hitesh. 2012.Water Quality Analysis of an Organically Polluted Lake by Investigating Different Physical and Chemical Parameters. Int. J. Res. Chem. Environ., 2 (1): 105-111.

World Health Organization. 2004. Guidelines for drinking water quality. $3^{\text {rd }}$ edn. WHO press, Switzerland. Pp.16, 89.

\section{How to cite this article:}

Sivamanikandan, P., and Ahmed john, S. 2016. Physical and chemical analysis of mullaiperiyar river water in Theni district, Tamilnadu, India. Int.J.Curr.Microbiol.App.Sci. 5(2): 173-180. doi: http://dx.doi.org/10.20546/ijcmas.2016.502.020 